\title{
NATIONAL GREEN TRIBUNAL OF INDIA AND ENVIRONMENTSAL JUSTICE
}

\section{Dr. Prachi V. Motiyani}

\begin{abstract}
Improving the environmental rule of law, access to justice and environmental dispute resolution is essential for achieving the UN's 2030 agenda for Sustainable Development and the Sustainable Development Goals (SDGs), particularly SDG Goal 16-'to provide access to justice for all and build effective, accountable and inclusive institutions at all levels', according to Pring and Pring (2016). To accomplish this goal, establishing specialised courts and tribunals dealing exclusively with environmental matters is becoming essential. All over the world, more than 1200 environmental courts and tribunals are functioning in various countries, and more such courts have been planned for the future, as discussed by Pring and Pring (2016).
\end{abstract}

As far as India is concerned, the need for establishing environmental courts in India arose in different circumstances and in different times. In the cases of M.C. Mehta Vs. Union of India (AIR 1987 SC 965), Indian Council for Enviro-Legal Action Vs. Union of India (1996 3 SCC 212) and A.P. Pollution Control Board Vs. Professor M.V. Nayudu (1992 2 SCC 718), the Indian Supreme Court (orders of 1986, 1996, 2001) observed that as environmental cases frequently involve assessment of scientific data, setting up environmental courts on a regional basis with a legally qualified judge and two experts would help speed the judicial process.

Key Words: National Green Tribunal, Indian Constitution, Environment Protection

\section{INTRODUCTION}

Many countries have their separate "Green Courts" or "Environmental Courts" to deal with Environmental Issues. Indian Government has formed National Green Tribunal (NGT) in the year 2010 and India become third country to establish special Court for Environmental issues 
after Australia and Newzeland . National Green Tribunal has established under Article 21 of the Indian Constitution. NGT is a unique judicial mechanism in the sense that it is a fast track 'quasi-judicial' body which deals only with the environment related civil litigations. Before NGT has evolved, there were two previous efforts to establish green courts in India. These were National Environment Tribunal Act, of 1995 (META) and National Environment Appellate Authority Act, of 1997 (NEAA). However, the most effective environment court in the form of NGT has come into reality in 2010. After its establishment, NGT has settled many environmental issues and has got overwhelm response from different corners. This study conducted an empirical analysis of NGT judgments since its inception in October 2010 to December 2013. It analyzes the Impact of NGT, the locations of conflicts. Special emphasis is given to the Coastal Zone management-related conflicts settled in NGT. Although there many limitations in NGT act and its procedures, it can be viewed as a positive step towards the environmental justice in India ${ }^{1}$.

\section{LEGAL FRAMEWORK PERTAINING TO ENVIRONMENT IN INDIA}

It is evident from the construction of the Constitution that the idea of environment was never there in the minds of the founding fathers of the Indian Constitution. Consequently, the expression 'environment' does not find any mention in the Constitution. However, there are many items in the legislative lists which enable the Centre and the State to make laws in the field of environment like public health, sanitation, agriculture etc.

Moreover, it is interesting to note that all the substantial steps taken by the State towards the protection of environment were taken after the Stockholm Conference, 1972. ${ }^{2}$ Prior to the conference, it did not hit the conscious of the Indian government that they need to proactively work towards safeguarding the environment.

The Constitution 42nd Amendment Act, 1976 which moved forest, wildlife and population control from the State to the Concurrent List enabling both the state and the centre to make laws pertaining to these areas is one of the examples out of the several initiatives taken by the Indian Government towards environment protection.

\footnotetext{
${ }^{1}$ https://www.researchgate.net/publication/266676371_National_Green_Tribunal_and_Environmental_Justice_i n India

${ }^{2}$ United Nations Conference on the Human Environment, Sweden 1972
} 
There is no doubt in saying that it is the responsibility of the State to protect the environment. However, it took a long time for the Apex Court to pronounce explicitly that the right to life under Article $\mathbf{2 1}^{\mathbf{3}}$ of the Constitution contains right to have a healthy environment.

The Constitution of India directs the State to endeavour to protect and improve the environment and to safeguard the forest and wildlife of the country. ${ }^{4}$ Article 51(g) of the constitution states that it shall be the duty of every citizen of India to protect and improve the national environment including forests, lakes, rivers and wildlife and to have compassion for living creatures. The language of the Directive principles of the state policy (Article 47) also contains a specific provision, which commits the state to protect the environment.

To protect and improve the environment is a constitutional mandate. ${ }^{5}$ It is a commitment for a country wedded to the ideas of a welfare State. The Indian Constitution contains specific provisions for environment protection under the chapters of Directive Principles of State Policy and Fundamental Duties. ${ }^{6}$ The absence of a specific provision in the Constitution recognizing the fundamental right to clean and wholesome environment has been set off by judicial activism in the recent times.

Article 49-A: "The State shall endeavour to protect and improve the environment and to safeguard the forests and wildlife of the country."

The said amendment imposed a responsibility on every citizen in the form of Fundamental Duty.

\section{Article 51-A (g) which deals with Fundamental Duties of the citizens states:}

"It shall be the duty of every citizen of India to protect and improve the natural environment including forests, lakes, rivers and wildlife and to have compassion for living creatures."

Thus, protection and improvement of natural environment is the duty of the State (Article 48A) and every citizen (Article 51- A (g)).

\footnotetext{
${ }^{3}$ M.P. Jain's Indian Constitutional Law, Lexis Nexis, $\left(7^{\text {th }}\right.$ Ed)

${ }^{4}$ P. Leela Krishnan, Law and Environment, 1992, p. 7

${ }^{5}$ Virendra Gaur v. the State of Haryana, (1995) 2 SCC 577

${ }^{6}$ Research Foundation for Science Technology National Resource Policy v. The Union of India, (2002) 8 SCC 481
} 
In the case of Kinkri Devi v. State of H.P., ${ }^{7}$ the Himachal Pradesh High Court laid down that in view of Articles 48 (A) and 51-A (g) there is both a constitutional pointer to the State and a constitutional duty of the citizens not only to protect but also to improve the environment and to preserve and safeguard the forests, the flora and fauna, the rivers and lakes and all other water resources of the country. The neglect or failure to abide by the pointer or to perform the duty is nothing short of a betrayal of the fundamental law which the State and, indeed, every Indian, high or low, is bound to uphold and maintain. Otherwise the Court cannot remain a silent spectator to ensure the attainment of the constitutional goal of the protection and improvement of environment, the Court can intervene effectively by issuing appropriate writs, orders and directions.

Article 253 states that 'Parliament has power to make any law for the whole or any part of the country for implementing any treaty, agreement or convention with any other country'. In simple words this Article suggests that in the wake of Stockholm Conference of 1972, Parliament has the power to legislate on all matters linked to the preservation of natural environment. Parliament's use of Article 253 to enact Air Act and Environment Act confirms this view. These Acts were enacted to implement the decisions reached at Stockholm Conference. ${ }^{8}$

Indian Constitution is amongst the few in the world that contains specific provisions on environmental protection. The Indian Constitution is the first Constitution in the world made a provision for the protection of environment. ${ }^{9}$ The directive principles of state policy and the fundamental duties chapters explicitly enunciate the national commitment to protect and improve the environment.

The Constitution being Supreme law of the land shall be binding on not only the citizens and non-citizens but also on the State itself.

Thus, it is clear that our Constitution enshrines ample provisions to deal with environmental pollution. Under these a good number of statutes have been passed and they are capable of producing desired results. Accordingly to the N.D. Tewari Committee Report, ${ }^{10}$ there are

\footnotetext{
${ }^{7}$ AIR 1988 HP 4 also General Public of Saproon Valley v. State of HP, AIR 1993 HP 52

${ }^{8}$ United Nations Conference on the Human Environment, Sweden 1972

${ }^{9}$ C.M. Jariwala, "The Constitution 42nd Amendment Act and the Environment", Legal Control of Environmental Pollution, 1980, p. 1

${ }^{10}$ This Committee was constituted by the Government of India, Department of Science and Technology to make recommendation regarding Legislative measures and Administrative Machinery for ensuring Environmental Protection. Report was submitted by the Committee in September 1980
} 
two hundred Central and State Statutes which have some bearing on environmental protection. However, the provisions contained therein are not more than piecemeal legislations pertaining to environment. The truth is that these scattered provisions were made keeping in mind something different from environment. However, under the impact of Stockholm Declaration attention is focused on the question of environment and new legislations have come into existence.

\section{Articles 48-A and 51-A. Clause (g):}

Initially, the Constitution of India had no direct provision for environmental protection. Global consciousness for the protection of environment in the seventies, Stockholm Conference and increasing awareness of the environmental crisis prompted the Indian Government to enact 42nd Amendment to the Constitution in 1976. The Constitution was amended to introduce direct provisions for protection of environment. This 42nd Amendment added Article 48-A to the Directive Principles of State Policy ${ }^{11}$.

\section{JURIDICTION OF NGT}

The NGT replaced the existing National Environment Appellate Authority of the Ministry of Environment and Forest. The tribunal, according to the NGT Act of 2010, shall have the 'jurisdiction over all civil cases where a substantial question relating to environment (including enforcement of any legal right relating to environment) is involved and such question arises out of the implementation of the enactments specified in Schedule I', namely The Water (Prevention and Control of Pollution) Act of 1974, the Water (Prevention and Control of Pollution) Cess Act of 1977, The Forest (Conservation) Act of 1980, The Air (Prevention and Control of Pollution) Act of 1981, The Environment (Protection) Act of 1986, The Public Liability Insurance Act of 1991 and The Biological diversity Act of 2002.

At present, the NGT is functional in five locations. New Delhi is the principal seat of the Tribunal (Principal Bench) and Bhopal (Central Zone), Pune (West Zone), Kolkata (East Zone) and Chennai (South Zone) are the other seats of the tribunal as zonal benches. By establishing zonal benches, people from different parts of the country can have access to the tribunal. Each tribunal will have Judicial and Expert Members. Additionally, the NGT constituted circuit benches to convene in places, viz. Shimla, Shillong, Jodhpur and Kochi, to hear cases pertaining to particular states. This was mainly to reduce the constraints of

\footnotetext{
${ }^{11} 42^{\text {nd }}$ Amendment to the Constitution, 1976
} 
accessibility, especially for the poor and tribal populations living in remote areas of the country. $^{12}$

There were 510 judgements delivered by NGT in 2016 and they were classified under different sectors of environmental law. This was done considering the jurisdictions of the NGT. When NGT was established, it was defined that NGT would adjudicate on the matters coming under the various Acts, viz. The Water (Prevention and Control of Pollution) Act, 1974, The Water (Prevention and Control of Pollution) Cess Act, 1977, The Forest (Conservation) Act, 1980, The Air (Prevention and Control of Pollution) Act, 1981, The Environment (Protection) Act, 1986, The Public Liability Insurance Act, 1991 and The Biological Diversity Act, 2002. Accordingly, the judgements were classified into different environmental sectors, namely Air, Water, Waste, Noise, Nature, Industry Operations, Thermal Power Plants, Mining Operations, Environmental Compensations and Others.

\section{ENVIRONMENTAL COMPENSATION AWARDED BY NGT}

Samir Mehta Vs. Union of India and Others, as per the judgement dated 23-08-2016, the NGT directed that an environmental compensation to be paid by the Respondent of concern for the damage caused to the ecosystem, loss to ecology and livelihood in accordance with the 'Polluter Pays Principle'.

In the matter of Manoj Mishra Vs. Union of India and Others, as per the Judgement dated 1301-2015 pertaining to the clean and rejuvenated Yamuna River, Delhi, the NGT issued directions to the Civic and Municipal authorities of Delhi to charge every household an environmental compensation fee as part of the property/house tax. Similarly, in the case of Krishan Kant Singh Vs. National Ganga River Basin Authority (2014), NGT directed, in its judgement delivered on 16 October 2014, the defaulting industrial unit to pay a compensation of Rupees Five Crores to the concerned State Pollution Control Board based on the Polluter Pays Principle for undertaking remedial activities to ensure river conservation. In another judgement (R K Patel Vs. Union of India, judgement delivered 18 February 2014), the NGT directed for environmental compensation of Rupees Ten Lakhs to the aggrieved farmers at Vapi, Gujarat due to the hazardous waste pollution.

\footnotetext{
12 National Green Tribunal of India - an observation from environmental judgements https://link.springer.com/article/10.1007/s11356-018-1763-2
} 


\section{CONCLUSION}

The progress of environmental justice in India has been on increasing trend, with effective usage of NGT. NGT is seen as 'Responsive to Environmental Problems', as one of the characteristics of any successful environmental court.

Dr. Prachi V. Motiyani 